\title{
Modelling the Accommodation Preferences of Tourists by Combining Fuzzy-AHP and GIS Methods
}

\author{
Ali Mahdi $\mathbb{D}^{1,2}$ and Domokos Esztergár-Kiss $\mathbb{D}^{1}$ \\ ${ }^{1}$ Department of Transport Technology and Economics, Faculty of Transportation Engineering and Vehicle Engineering, \\ Budapest University of Technology and Economics, Müegyetem rkp. 3., 1111, Budapest, Hungary \\ ${ }^{2}$ Department of Construction and Projects, University Headquarter, University of Anbar, Ramadi, Iraq
}

Correspondence should be addressed to Ali Mahdi; alijamalmahdi@edu.bme.hu

Received 29 March 2021; Revised 28 June 2021; Accepted 3 August 2021; Published 3 September 2021

Academic Editor: Seungjae Lee

Copyright ( 2021 Ali Mahdi and Domokos Esztergár-Kiss. This is an open access article distributed under the Creative Commons Attribution License, which permits unrestricted use, distribution, and reproduction in any medium, provided the original work is properly cited.

\begin{abstract}
Finding the place of accommodation is one of the most crucial issues during a journey. This study aims to support the decisionmaking of tourists for choosing the optimal accommodation by combining fuzzy analytic hierarchy process (FAHP) and geographic information system (GIS) techniques. The adopted criteria are the cost per room, the distance from the center, the level of security, the place rating, and the availability of free cancellation and breakfast. Due to some uncertainty and diversity of criteria, the FAHP approach is applied to consolidate tourists' decisions by applying criteria weighting, while the GIS is used to overlay the weighted criteria and to visualize the ranked places of accommodation on a map. The combined technique is applied on a case study in Budapest City, where the analysis is conducted on 364 places of accommodation. The results show that half of the places are recommended for tourists, and more than fifth of the accommodations are highly recommended. Furthermore, it can be concluded that the cost per room was the highest influential criterion with 0.233 importance weight, followed by the security level with 0.205 . The lowest factor affecting the choice of accommodation was the free cancellation service. It was demonstrated that the rating weight importance was 0.182 , while the breakfast and the distance from the center had approximately the same importance. As a recommendation, some improvements on the accommodation, such as decreasing the cost per room, enhancing the services, or developing the quality of the places, would increase their attractiveness for tourists.
\end{abstract}

\section{Introduction}

For several countries, tourism is one of the most important industries in terms of the gross domestic product (GDP) [1]. Data collection about the cities is a relevant issue, where several parameters have to be considered [2]. According to the Hungarian Central Statistical Office, tourism industry is around the fifth of the country's economic activities. The direct and indirect economic influence of tourism in Hungary was about $9.4 \%$ in 2015 where more than 20 million tourists arrived in Hungary [3]. Tourism can be defined as the tourists' travelling for leisure or other goals and staying outside their common environment for a specific period, not exceeding one continuous year. Tourism industry involves entertainment destinations (recreation, culture, sports activities, etc.), food establishments (restaurants, cafes, taverns, etc.), places of accommodation (hotels, motels, campgrounds, etc.), transportation (airplane, rail, bus, auto, etc.), shopping facilities, and others [4]. Accommodation is the most important sector in tourism industry, where more than two fifths of tourists' daily expenditures are allocated to this sector [5]. The places of accommodation represent the locations, where tourists can rest and plan their activities [6].

In major touristic cities, there is a lot of uncertainty about choosing the optimal places of accommodation. Finding an optimal accommodation is one of the most important decisions in the tourists' journeys [7]. Despite the availability of online websites and applications for booking accommodation, the issue is still complex due to the extensive number of available options in this sector and the 
numerous factors that affect the decision-making. Although there is heterogeneity of the characteristics of the tourists themselves, such as the sociodemographic (gender, age, marital status, educational level, and income), the questions seem to be the same: where can I sleep safely and secure? How much is the cost per night? Does accommodation provide services such as breakfast or free cancellation? [8].

In case of a spatial problem, such as the accommodation search, where several criteria have to be considered, multicriteria decision-making (MCDM) methods can be applied. More specifically, in case of uncertainty and fuzzy conditions, the fuzzy analytic hierarchy process (FAHP) method, which is a specific type of an analytic hierarchy process (AHP) and belongs to the MCDM methods, can be used. For example, a study mentioned that tourists face difficulties when choosing the optimal restaurant in a foreign city, which choice includes some subjective elements. Dewi et al. [9] performed a comparison among the AHP, FAHP, and TOPSIS methods using a mobile-based culinary recommendation system. The outcomes proved that FAHP had the highest accuracy compared to the other methods. The concept of FAHP can be also used for evaluating the criteria that affect the accommodation choice, while it would be difficult to use the traditional method (i.e., AHP) because of dealing with a fuzzy environment. Based on the reasons stated above, the FAHP method combined with geographic information system (GIS) technique could offer wellestablished choices for tourists. Thus, the main objective of this study is to develop a comprehensive model, which supports tourists in choosing the optimal accommodation according to their preferences and constraints.

This paper is organized as follows: after the introduction, Section 2 reviews previous studies which use GIS and MCDM methods. The theoretical methods and the proposed methodology are explained in Section 3. The results and the study area are explained in Section 4, followed by the discussion in Section 5. Finally, the main conclusions are demonstrated in Section 6.

\section{Literature Review}

Accommodation facilities vary in size and services, but their primary purpose is to provide customer service, where hotels, motels, guesthouses, and apartments are examples of places of accommodation [10]. Tourists choose the place according to their preferences and constraints, where cost, location, and services represent the basic elements of the consideration [11]. Many studies examine the factors that affect the tourists' choices of accommodation. Psychological and nonpsychological factors influence the decision-making process, especially in the field of tourism due to the variety and the competition among the alternatives [12]. Losada et al. [13] conducted a study on the types of accommodation chosen by senior tourists in Spain. An interview survey through telephone was used to obtain data, such as sociodemographic and self-perceived variables as well as factors linked to pull motivation. A multinomial logit model was applied to analyze the collected data. The study found that seven out of ten senior tourists preferred hotels.
Additionally, the outcomes indicated that the staying's length highly correlates to the type of accommodation. Another study by [14] considered the global economic crisis's impact on the accommodation of tourists in the Netherlands. The researchers mentioned that affordable hotels play a significant role in tourists' choices. Ananth et al. [15] examined a sample of tourists to evaluate the factors affecting hotel selection. The results demonstrated that the price and the hotel quality were the most influential factors. Another research was carried out by [16], who found that the cost, the location, the cleanliness, and the services are the most persuasive factors in the tourists' accommodation choices. In another study, it was found that factors related to the hotels, such as the size of the room or the provision of breakfast, have a significant effect on tourists' choices [17].

For the location selection process of the accommodation, the decision-maker tries to choose the facility that could fulfil his/her requirements, where several factors for the optimal selection have to be considered. MCDM technique is applied to evaluate and rank the multicriteria problems [18]. Chou et al.[19] applied MCDM (more specifically a fuzzy method) for selecting international hotel locations in Taiwan. The findings proved that the security level, accessibility, and the surrounding cultures are the most important criteria for hotel location selection. Similarly, Sohrabi et al. [20] applied the fuzzy model to analyze the factors that affect hotel selection in Iran. They divided the factors into two main groups: hotel comfort factors and hotel compensatory factors. The first group involved hotel staff, promenade and comfort, pleasure, car parking, network services, and rooms' cleanliness. Security, expenditure, and recreational information refer to the second main group. The main results revealed that the high importance criteria were the expenditure and car parking since most tourists come from poorer cities of Iran. Hsu et al. [21] combined the fuzzy method and TOPSIS to identify the prioritizing factors that affect the destination choice of tourists. The scholars evaluated eight touristic destinations in Taiwan. The final result showed that safety and visiting friends significantly influenced the tourists' destinations, while the cost had the least effect. Ngai and Wat [22] developed a fuzzy expert system called the hotel advisory system (HAS) to help tourists in choosing their hotels. The final evaluation of experts and users revealed the benefit of the system and positive feedback from the questionnaires survey. Thus, MCDM can be applied in order to consider all the influential factors concerning the choice of the optimal place. The most appropriate approach to evaluate the alternative is MCDM, especially for the site selection problems [23].

During the last few years, GIS plays a significant role in assisting the decision-making process by dealing with spatial data and generating the suitability maps [24]. According to [25] definition, GIS is a tool used to capture, store, check, integrate, manipulate, analyze, and display spatial data. Due to the capabilities of GIS, it has been applied in different disciplines for a variety of complex spatial problems. Moreover, several studies applied this tool in tourism. For example, García-Palomares et al. [26] investigated the role of GIS in tourism planning, where tourists' hot spots are 
identified in eight major European cities, and the distribution pattern is analyzed based on spatial GIS techniques. Another comprehensive study discussed the role of the GIS in tourism [27]. The study aimed to explain the importance of the GIS in tourism through the analysis of data, modelling, and forecasting in the tourism field.

In order to find the suitability of an area, GIS techniques based on MCDM could be used. The combination of MCDM and GIS could improve the capabilities of handling variety and the amount of spatial data [28]. Ibraheem et al. [29] used GIS-AHP combination to explore car parking's optimal location in the CBD of Al Ramadi City, Iraq. The AHP method generated the weight of the criteria, and GIS techniques were applied for the final suitability map. Similarly, Mishra et al. [30] applied GIS and AHP to identify the suitable locations of organic farming. The scholars mentioned that rural tourism and economics could be promoted by developing organic farming in rural regions. The weights of the adopted criteria were calculated with the AHP method. Then, the overlaying tool of GIS was used to generate the map. GIS-based MCDM is a suitable method for dealing with multicriteria spatial problems as shown by [31]. They applied this approach to the northern touristic areas of Iran. Analytical network process (ANP) has been used with GIS-MCDM. The results showed the highest potential tourists area based on the natural environmental features. With the same approach, Sahin et al. [32] evaluated air pollution problems in Turkey. Alam [33] combined AHP and GIS to select the optimal accommodation for living in Chittagong City, Bangladesh. He mentioned that using this combination (i.e., GIS and MCDM) is a useful approach that facilitates the users to evaluate the numerous alternatives. The study helped the clients easily to choose the optimal location for accommodation. The combination of GISMCDM is an excellent approach to simplify a complex problem, as mentioned by [34]. However, only a few studies applied this framework in the tourism sector.

Several studies in various disciplines applied a similar methodology to solve an MCDM problem. Table 1 provides a detailed overview of the applied methodology in previous studies taking into account the decision goal, the method approach, the type of the problem, the relevance to tourism sector, and the studied criteria. It can be stated that none of these papers consider the accommodation choice in tourism as an MCDM-spatial problem.

The decision-making for selecting the optimal accommodation becomes complicated due to the multiple criteria that affect the process, as a variety of places can be found based on quality, service availability, rating, accessibility, cost, and location. Thus, FAHP could be used to tackle the fuzziness related to the criteria evaluation, as it can reflect the way of decision-makers' thinking as they can express their judgment in an interval rather than using a single value [35]. Moreover, FAHP is a method that deals with uncertainty to generate decisions [36]. All these advantages make FAHP the appropriate method for the complex decision of choosing the optimal accommodation place. The combination of FAHP and GIS would produce the final suitability map of accommodations for tourists in Budapest.

\section{Methodology}

3.1. Structure and Criteria. This study was performed in two main phases: the first phase applied FAHP to find the criteria's weight. After collecting the relevant data and preparing the study area's layers using the GIS, the second phase conducted that represents the combination of the outcomes of the first phase and overlay GIS tool to generate the final map. Through two phases, classification process of the alternatives is performed, see Figure 1.

The combination of FAHP and GIS techniques is applied to analyze the locations of accommodations. A crucial step of this approach is the identification of the relevant criteria that can be found in the majority of the online accommodation reservation applications and websites, such as booking.com. The suitable criteria have been chosen based on the literature review and discussions with transport experts and researchers. Figure 2 shows the hierarchical structure that involves the goal, the criteria, and the alternatives considered in this study.

The data have been collected from [37] website. Meanwhile, the number of crimes per district for Budapest City was collected from [38]. These data are utilized to identify the level of security in the study area. Then, the spatial analysis and classification of accommodation places according to the security level criterion was achieved. The criteria can be detailed as follows:

Place rating: the reviews of the customers are used to represent the rating of each accommodation. In case of a missing rating, it is assumed to be equal to the lowest value.

Cost per room: the cost of a single room for one night is calculated.

Distance from the center: the distance from the city center in $\mathrm{km}$ is used as an indicator of this criterion.

Breakfast included: if the places do not offer this service, 0 value is assumed. Otherwise, the value is equal to 1 .

Level of security: the value of this criterion is obtained based on the number of crimes per each district and the coordination of the places.

Free cancellation: if the accommodations do not offer this service, 0 value is assumed. Otherwise, the value is equal to 1 .

Booking.com is one of the biggest websites for accommodations and used for gathering the related data. Octoparse. 8 software is applied to scrape the accommodation places of Budapest City in a CSV-file. Then, Excel software used to organise, filter, and summarise the collected attribute data, especially with scraping a website where repeated data might be found. The spatial data of the study area are collected by using Open Street Map (OSM) based on QGIS software (version 3.10.9). The clip tool of ArcGIS 10.5 software is applied to identify the study area of Budapest City. Then, the spatial data are connected with the attribute data to prepare the layers to be used for spatial analysis and classification and as an input layer in the overlay weighted step. 
TABLE 1: Comparison of the applied methodology in this study and previous studies.

\begin{tabular}{|c|c|c|c|c|c|c|}
\hline Reference & Decision goal & $\begin{array}{l}\text { MCDM } \\
\text { approach }\end{array}$ & $\begin{array}{l}\text { MCDM- } \\
\text { spatial } \\
\text { problem }\end{array}$ & $\begin{array}{l}\text { MCDM- } \\
\text { GIS }\end{array}$ & $\begin{array}{l}\text { Tourism } \\
\text { sector }\end{array}$ & Studied criteria \\
\hline [19] & $\begin{array}{l}\text { Hotel location building } \\
\text { choice }\end{array}$ & FAHP & Yes & No & Yes & $\begin{array}{l}\text { Proximity to public facilities, cost, distance to } \\
\text { existing competitors, security, natural } \\
\text { resources, rest facilities, distances, parking } \\
\text { area, convenience, leisure facilities, diversity } \\
\text { of restaurants, local culture, quality of } \\
\text { manpower, and regulation restrictions }\end{array}$ \\
\hline [29] & Car parking location & AHP & Yes & Yes & No & Accessibility, land-use, location, and cost \\
\hline [31] & Potential touristic area & ANP & Yes & Yes & Yes & $\begin{array}{l}\text { Water attractions, scenic spots, mountain } \\
\text { attractions, and forest attractions }\end{array}$ \\
\hline [30] & $\begin{array}{l}\text { Optimal locations for } \\
\text { organic farming }\end{array}$ & AHP & Yes & Yes & No & $\begin{array}{c}\text { Road, drainage, soil, slop, geology, and land- } \\
\text { use/land cover }\end{array}$ \\
\hline [32] & $\begin{array}{l}\text { Optimal region for } \\
\text { installing air pollution }\end{array}$ & AHP & Yes & Yes & No & Topographic and weather parameters \\
\hline [33] & $\begin{array}{l}\text { Optimal } \\
\text { accommodation place }\end{array}$ & MCS & Yes & Yes & No & $\begin{array}{l}\text { Road, market, hospital, university, office, } \\
\text { beach, school, police station, playground, } \\
\text { park, and airport }\end{array}$ \\
\hline $\begin{array}{l}\text { Proposed } \\
\text { study }\end{array}$ & $\begin{array}{l}\text { Optimal } \\
\text { accommodation place } \\
\text { for tourists }\end{array}$ & FAHP & Yes & Yes & Yes & $\begin{array}{l}\text { Cost per room, distance from the center, level } \\
\text { of security, place rating, and availability of } \\
\text { free cancellation and breakfast }\end{array}$ \\
\hline
\end{tabular}

3.2. FAHP. Choosing a place of accommodation involves an uncertainty circumstances. Thus, the application of a simple AHP method may be not efficient and might lead to inaccurate results [39]. A combination of AHP and fuzzy approach helps to select the optimal place. A pairwise comparison is conducted based on the criteria. The comparison is performed by using the AHP scale from 1 to 9. A survey has to be conducted with a group of experts to evaluate the relevant criteria. It is common to use a limited number of experts. Various research studies reported outcomes using MCDM with a small number of experts, such as the studies [40, 41] utilized only 5 participants, the study [42] worked with 7 participants, and the study [43] used input from 17 participants.

The consistency ratio (CR) of the pairwise comparison matrices is calculated according to [44]. Equations (1) and (2) are used for checking CR, which value should be below $10 \%$ :

$$
\begin{aligned}
& \mathrm{CI}=\frac{\lambda_{\max }-n}{n-1}, \\
& \mathrm{CR}=\frac{\mathrm{CI}}{\mathrm{RI}} \leq 0.1,
\end{aligned}
$$

where CI represents the consistency index, $\lambda_{\max }$ is the maximum eigenvalue, $n$ refers to the number of rows in a matrix, and RI is the random index, which values can be seen in Table 2.

Each expert assigns a term according to the AHP scale. Then, the extented FAHP version is applied to calculate the overall weights. The AHP scale is converted to fuzzy numbers by using the triangular fuzzy number (TFN). The membership function of the fuzzy theory indicates a new scale ranging from 0 to 1 . Thus, new terms can be used to obtain a range of numerical numbers. Letters $l, m$, and $u$ are used to identify the triangular fuzzy numbers (TFN), where $l$, $m$, and $u$ denote the lower, medium, and upper numbers of TFN, respectively. Equation (3) and Figure 3 illustrate the membership function of a TFN [45]:

$$
\mu M(x)= \begin{cases}\frac{x}{m-l}-\frac{l}{m-l}(\text { Placeholder } 1), & x \in[l m], \\ \frac{x}{m-u}-\frac{u}{m-u}, & x \in[m u], \\ 0, & \text { otherwise. }\end{cases}
$$

The AHP scale is converted to fuzzy numbers (as shown in Table 3) by using the triangular fuzzy number (TFN).

The calculation of the weights of the criteria by using the extended version of FAHP can be summarized as follows.

Step 1. After checking the consistency ratio of the experts' opinions, the pairwise comparison matrices are converted into fuzzy numbers. Equations (4)-(6) are used to obtain the individual judgment matrix based on the studies of [46], [47], and [48]:

$$
\begin{aligned}
l_{i j} & =\min _{k=1,2, \ldots, k}\left(l_{i j k}\right), \\
m_{i j} & =\sqrt[k]{\prod_{k=1}^{k} m_{i j k},} \\
u_{i j} & =\max _{k=1,2, \ldots, k}\left(u_{i j k}\right),
\end{aligned}
$$

where $i$ and $j$ refer to the preference or relative importance for each criterion, as assigned by expert $k$. 


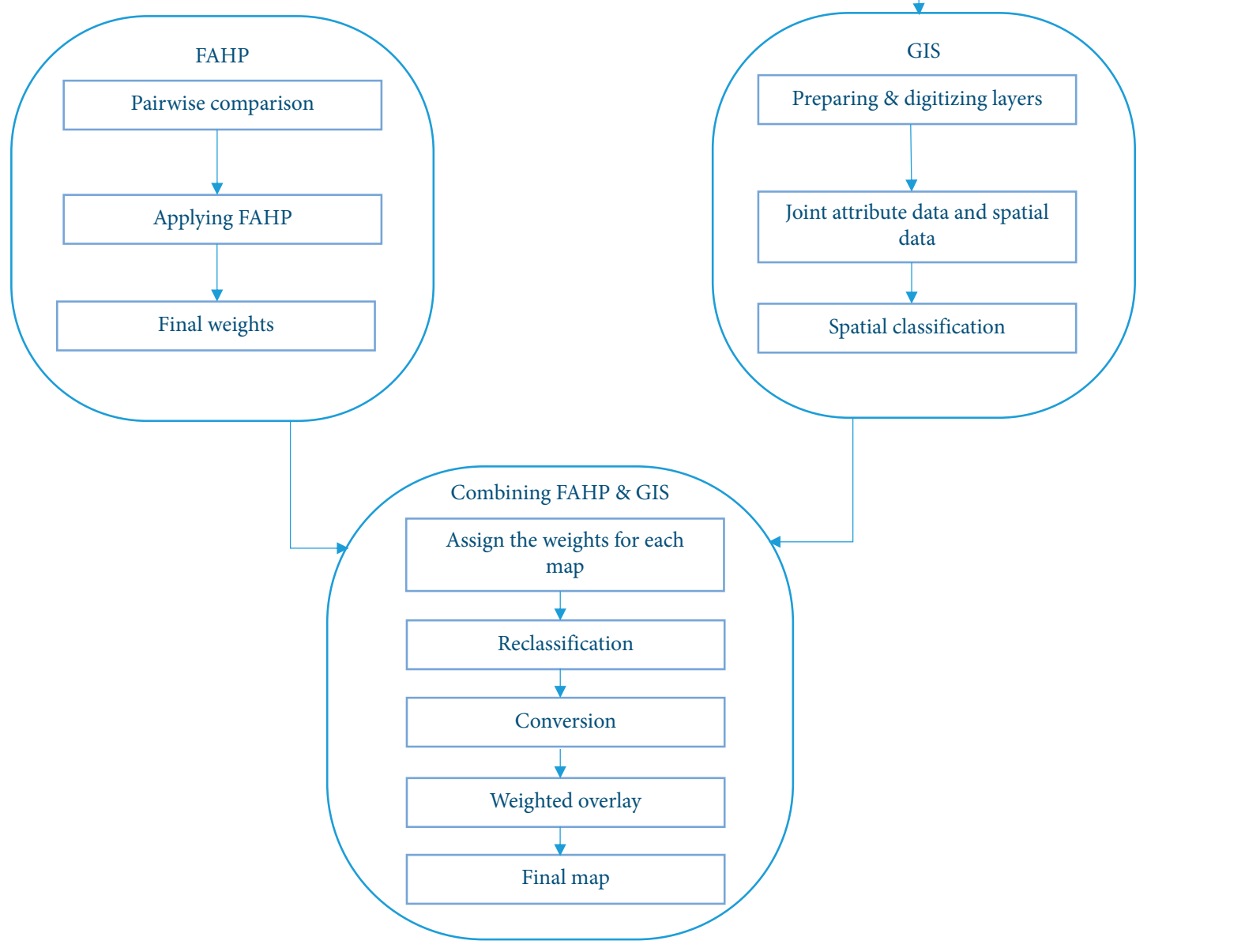

Figure 1: The representation of the methodology.

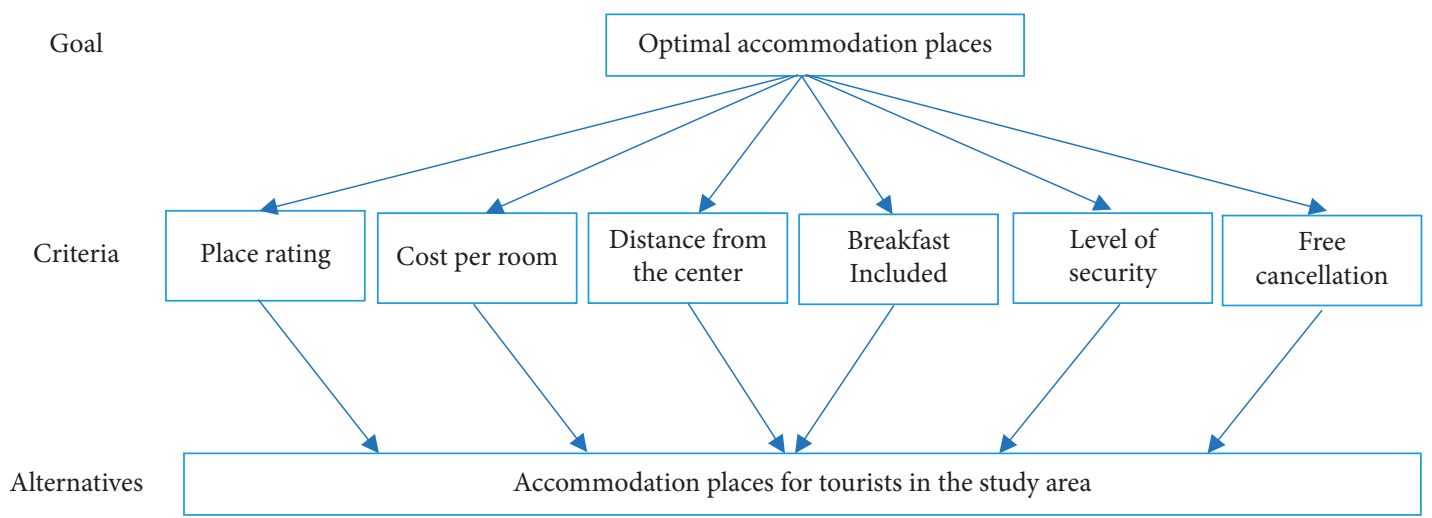

FIGURE 2: The hierarchical structure of the method to find a place of accommodation. 
TABLE 2: Random index of a matrix.

\begin{tabular}{cccccccc}
\hline$n$ & 3 & 4 & 5 & 6 & 7 & 8 & 9 \\
\hline $\mathrm{RI}$ & 0.58 & 0.9 & 1.12 & 1.24 & 1.32 & 1.41 & 1.45 \\
\hline
\end{tabular}

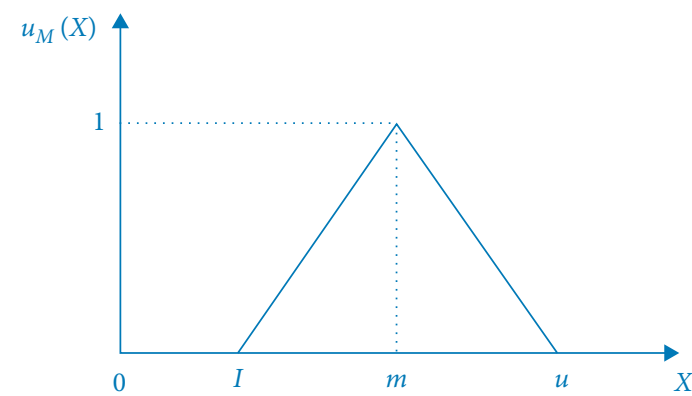

Figure 3: Triangular fuzzy number (TEN) [45].

Step 2. Let the object and the goal set be denoted by $x=\left\{x_{1}\right.$, $\left.x_{2}, \ldots, x_{n}\right\}$ and $G=\left\{g_{1}, g_{2}, \ldots, g_{n}\right\}$, respectively. Then, the extent analysis for each goal $g_{1}$ is performed. Moreover, the extent analysis is applied for each object:

$$
M_{g i}^{1}, M_{g i}^{2}, \ldots, M_{g i}^{m}, \quad i=1,2, \ldots \ldots, n .
$$

Thus, the calculation of the fuzzy value synthetic can be obtained for each object as shown in the following equations:

$$
S_{i}=\sum_{j=1}^{m} M_{g i}^{j} \times\left[\sum_{i=1}^{n} \sum_{j=1}^{m} M_{g i}^{j}\right]^{-1},
$$

where

$$
\begin{gathered}
\sum_{j=1}^{m} M_{g i}^{j}=\left(\sum_{j=1}^{m} l_{i}, \sum_{j=1}^{m} m_{i}, \sum_{j=1}^{m} u_{i}\right), \\
\sum_{i=1}^{n} \sum_{j=1}^{m} M_{g i}^{j}=\left(\sum_{j=1}^{m} l_{i}, \sum_{j=1}^{m} m_{i}, \sum_{j=1}^{m} u_{i}\right), \\
{\left[\sum_{i=1}^{n} \sum_{j=1}^{m} M_{g i}^{j}\right]^{-1}=\left(\frac{1}{\sum_{j=1}^{m} u_{i}}, \frac{1}{\sum_{j=1}^{m} m_{i}}, \frac{1}{\sum_{j=1}^{m} l_{i}},\right)}
\end{gathered}
$$

Step 3. In this step, the degree of possibility of two fuzzy numbers $M_{1}\left(l_{1}, m_{1}\right.$, and $\left.u_{1}\right)$ and $M_{2}\left(l_{2}, m_{2}\right.$, and $\left.u_{2}\right)$ is determined as shown in the following equation:

$$
V\left(M_{1} \geq M_{2}\right)=h g t\left(M_{1} \cap M_{2}\right)=\mu_{M_{2}}(d)= \begin{cases}1, & \text { if } M_{2} \geq M_{1}, \\ 0, & \text { if } l_{1} \geq u_{1} \\ \frac{l_{1}-u_{2}}{\left(m_{1}-u_{2}\right)-\left(m_{1}-l_{1}\right)}, & \text { otherwise }\end{cases}
$$

where $d$ denotes the highest intersection point $D$ between $\mu_{M_{1}}$ and $\mu_{M_{2}}$. In addition, the values of $V\left(M_{1} \geq M_{2}\right)$ and $V\left(M_{2} \geq M_{1}\right)$ are relevant to comparing $M_{1}$ and $M_{2}$.

Step 4. As illustrated in Figure 4, the degree of possibility for a convex fuzzy number to be greater than $k$ convex fuzzy numbers is determined as shown in the following equation:

$$
\begin{aligned}
& V\left(M \geq M_{1}, M_{2}, \ldots, M_{k}\right)=V\left[\left(M \geq M_{1}\right) \text { and }\left(M \geq M_{k}\right)\right] \\
& \quad=\min V\left(M \geq M_{j}\right), \quad i=1,2, \ldots, k .
\end{aligned}
$$

Assuming that $\omega_{i}^{\prime}=\min V\left(M_{i} \geq M_{k}\right)$, the weight vector is given based on the following equation:

$$
W^{\prime}=\omega_{1}^{\prime}, \omega_{2}^{\prime}, \ldots, \omega_{\text {in }}^{\prime} .
$$

Step 5. The final weight vectors are computed via a normalization step, and the nonfuzzy numbers $W$ are given by

$$
W=\left(\omega_{1}^{\prime}, \omega_{2}^{\prime}, \ldots, \omega_{\text {in }}\right)^{T} .
$$

The arithmetic operations can be summarized as follows [49]:

Addition : $\left(l_{1} m_{1} u_{1}\right)+\left(l_{2} m_{2} u_{2}\right)=\left(l_{1}+l_{2}, m_{1}+m_{2}, u_{1}+u_{2}\right)$,

Subtraction: $\left(l_{1} m_{1} u_{1}\right)+\left(l_{2} m_{2} u_{2}\right)=\left(l_{1}-l_{2}, m_{1}-m_{2}, u_{1}-u_{2}\right)$,

Multiplication : $\left(l_{1} m_{1} u_{1}\right) \times\left(l_{2} m_{2} u_{2}\right)=\left(l_{1} \cdot l_{2}, m_{1} \cdot m_{2}, u_{1} \cdot u_{2}\right)$,

$$
\text { Inverse : }\left(l_{1} m_{1} u_{1}\right)^{-1}=\left(\frac{1}{u_{1}}, \frac{1}{m_{1}}, \frac{1}{l_{1}}\right) \text {. }
$$


TABLE 3: The definition of AHP terms, the AHP ratio scale, and the associated fuzzy numbers.

\begin{tabular}{lcc}
\hline definition & AHP scale & Fuzzy number \\
\hline Equal importance & 1 & $(1,1,1)$ \\
Somewhat more important & 3 & $(2,3,4)$ \\
Much more important & 5 & $(4,5,6)$ \\
Very much more important & 7 & $(6,7,8)$ \\
Absolutely more important & 9 & $(9,9,9)$ \\
& 2 & $(1,2,3)$ \\
Intermediate values & 4 & $(3,4,5)$ \\
& 6 & $(5,6,7)$ \\
\end{tabular}

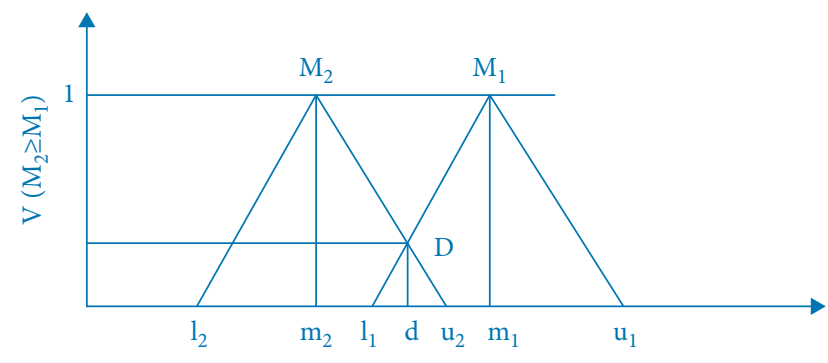

FIgure 4: The degree of possibility [45].

3.3. GIS Techniques with FAHP. ArcGIS 10.7 software is used to analyze the accommodations of tourists. The relevant layers are prepared and digitized as vector layers. Calculation processes are conducted on each alternative to standardize all the values on a unified scale. After linking the attribute data (i.e., collected data from booking.com website) with the prepared layers, a classification process is performed. For classification purposes, this study assumes the use of ten classes to formulate all the collected values except for the free cancellation and the breakfast availability, where the number of classes is two. This classification is based on the range of the maximum and minimum values of the collected data.

Then, the reclassification with the GIS tool is carried out to provide integer values instead of ranges. Thus, these values can be combined with FAHP results. The reclassified classes are based on the range of 1 to 10. For example, in case of the cost per room criterion, 10 is assigned for the lowest cost, while 1 is assigned for the highest cost. For the exception criteria, the classes are between 0 and 1, where 0 represents the unavailability of the services of breakfast or free cancellation, and 1 represents availability of these services. Then, the conversion of all reclassified layers from vector to raster is done by using the GIS tools. The converted layers represent the input data for the overlay step. This step includes the combination of FAHP outcomes and the integer values, which can be conducted using the GIS overlay tool. This process can be expressed as

$$
S_{(i, j)}=V_{(i)} \times W_{(j)},
$$

where $S_{(i, j)}=$ the final score of each alternative, $V_{i}=$ the score of each alternative $i$, and $W_{j}=$ the weight of each criterion $j$.

By using the overlaying tool within ArcGIS software, the final map (FM) can be produced. This step represents the summation of the final scores of each alternative. The produced map groups the alternatives into five classes. These classes include a range of recommended places from "highly recommended" to "not recommended." The final step can be expressed as

$$
\mathrm{FM}=\sum S_{(i, j)}
$$

\section{Results}

4.1. Case Study. Budapest is chosen as the location of the case study to analyze the places of accommodation for tourists. Rátz et al. [50] mentioned that Budapest is a major tourism destination in Hungary, and more than four-fifths of the tourists spent a night in the city. The city is the center of cultural and business tourism in Hungary, and it is rich in thermal baths, which makes the country the leader of health tourism in Europe [51]. Budapest consists of 23 districts, and most of the attractions, services, and facilities are located in the central part of the city [52]. Since the places of accommodation and the destinations of attractions are concentrated in the center of the city, only the inner area with 12 districts is selected as a case study. Pinke-Sziva et al. [53] mentioned that tourists prefer their accommodation in the central districts of Budapest City due to the concentration and variety of accommodation places (Figure 5). Thus, there is a high spatial concentration of the accommodation's demand in the city. This study collected the relevant data on accommodation places through searching for one room for one adult per only one night on 2 November was requested on booking.com website. The number of accommodation places was ca 525 places. However, 364 places of accommodation were considered and representing the most visited destinations for accommodation purpose in the city.

4.2. FAHP. The extended version of the FAHP is performed. In this phase of the study, the linguistic expressions are converted into numeric values according to FAHP concept. A survey was distributed to 21 experts and researchers in relevant fields of tourism and transportation, but only a total of 15 respondents completed it. As mentioned in the literature review section, having a relatively small sample size is not a critical issue from the MCDM methodology perspective. The consistency ratio of the 15 experts' preferences is checked using equations (1) and (2). Table 4 demonstrates the $\mathrm{CR}$ values of the experts, which do not exceed $10 \%$ in any of the cases. This means that the judgments were consistent, and the pairwise comparison matrices can be accepted. 


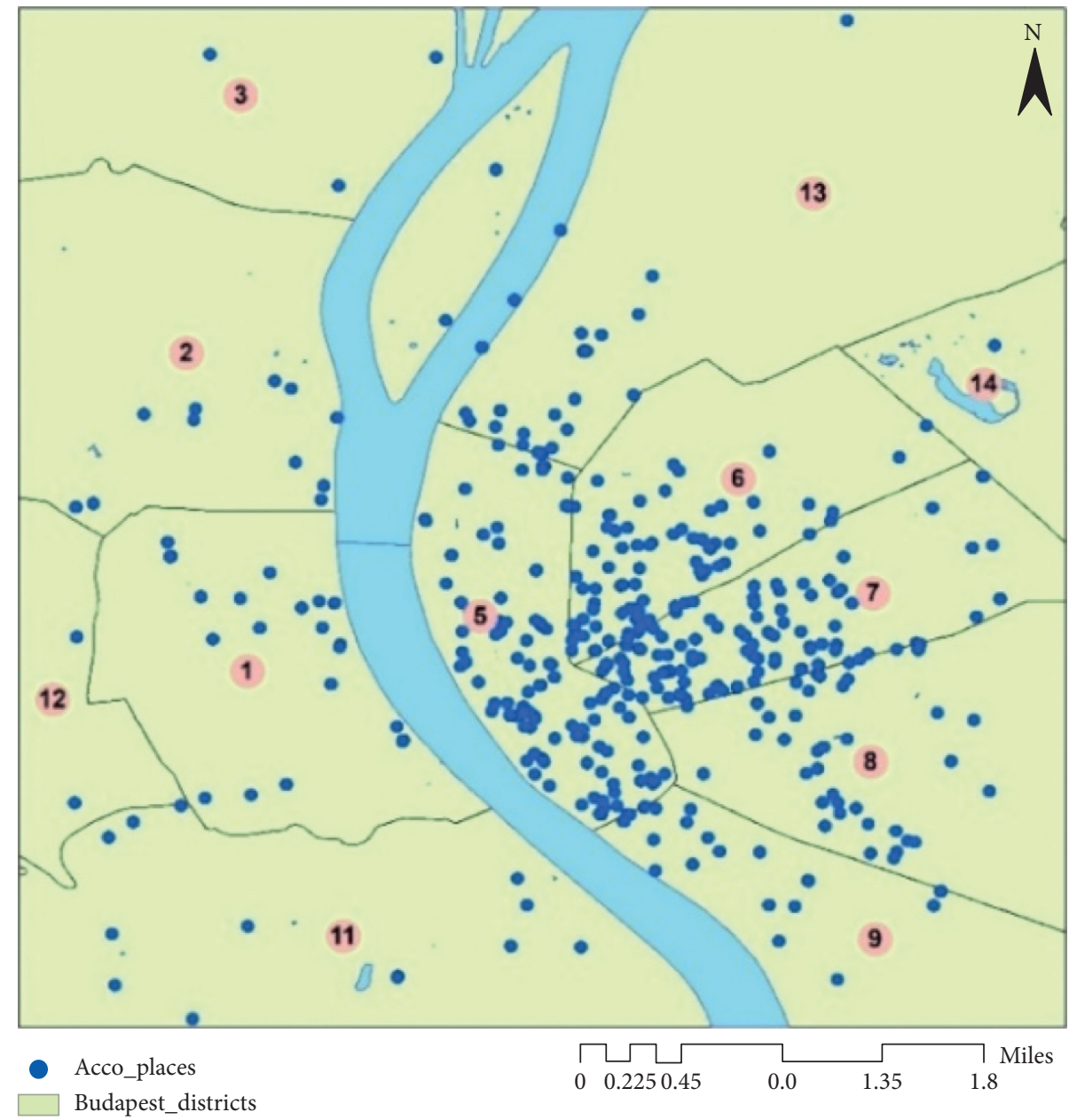

FIGURE 5: Places of accommodation in the study area.

TABLE 4: Results of consistency ratio $(n=6, \mathrm{RI}=1.24)$.

\begin{tabular}{|c|c|c|c|c|c|c|c|c|c|c|c|c|c|c|c|}
\hline & E1 & E2 & E3 & E4 & E5 & E6 & E7 & E8 & E9 & E10 & E11 & E12 & E13 & E14 & E15 \\
\hline$\lambda_{\max }$ & 6.52 & 6.58 & 6.45 & 6.36 & 6.50 & 6.55 & 6.54 & 6.56 & 6.58 & 6.53 & 6.63 & 6.49 & 6.64 & 6.63 & 5.57 \\
\hline CI & 0.10 & 0.12 & 0.09 & 0.07 & 0.10 & 0.11 & 0.11 & 0.11 & 0.12 & 0.11 & 0.13 & 0.10 & 0.13 & 0.13 & 0.11 \\
\hline CR & 0.08 & 0.09 & 0.07 & 0.06 & 0.08 & 0.09 & 0.09 & 0.09 & 0.09 & 0.09 & 0.10 & 0.08 & 0.10 & 0.10 & 0.09 \\
\hline
\end{tabular}

A pairwise comparison matrix is obtained by applying equations (4)-(6) (Table 5). Thus, Chang's extended version of AHP can be used to calculate the overall weights of criteria.
The values of the fuzzy synthetic can be computed by using equations (8)-(11). Equation (12) is used for the comparison and the calculation of the degree of two fuzzy numbers' possibility as follows: 
TABLE 5: FAHP preference comparison matrix.

\begin{tabular}{lcccccc}
\hline & $\mathrm{C} 1$ & $\mathrm{C} 2$ & $\mathrm{C} 3$ & $\mathrm{C} 4$ & $\mathrm{C} 5$ & C6 \\
\hline C1 & $(1,1,1)$ & $(0.13,0.21,0.5)$ & $(0.17,1,6)$ & $(0.17,2.35,9)$ & $(0.13,0.33,4)$ & $(2,4.90,9)$ \\
C2 & $(2,4.83,8)$ & $(1,1,1)$ & $(4,5.35,8)$ & $(2,6.11,9)$ & $(0.25,1.72,6)$ & $(6,8.36,9)$ \\
C3 & $(0.17,1,6)$ & $(0.13,0.19,0.25)$ & $(1,1,1)$ & $(0.25,2.21,8)$ & $(0.17,0.34,1)$ & $(2,4.51,6)$ \\
C4 & $(0.11,0.43,6)$ & $(0.11,0.16,0.5)$ & $(0.13,0.45,3)$ & $(1,1,1)$ & $(0.11,0.30,3)$ & $(0.25,1.43,7)$ \\
C5 & $(0.25,3,8)$ & $(0.17,0.58,4)$ & $(1,2.95,6)$ & $(0.33,3.35,9)$ & $(1,1,1)$ & $(1,5.36,9)$ \\
C6 & $(0.13,0.21,0.5)$ & $(0.11,0.12,0.17)$ & $(0.17,0.24,0.5)$ & $(0.14,0.55,4)$ & $(0.13,0.24,1)$ & $(1,1,1)$ \\
\hline
\end{tabular}

TABLE 6: Weight vectors and the normalized final weights of criteria.

\begin{tabular}{lccc}
\hline Explanation & Criteria & Weight vector $\left(W^{\prime}\right)$ & Final weight $(W)$ \\
\hline Place rating & C1 & 0.778 & 0.182 \\
Cost per room & C2 & 1.000 & 0.233 \\
Distance from the center & C3 & 0.713 & 0.166 \\
Breakfast included & C4 & 0.634 & 0.148 \\
Level of security & C5 & 0.877 & 0.205 \\
Free cancellation & C6 & 0.285 & 0.066 \\
\hline
\end{tabular}

$$
\begin{aligned}
& \operatorname{SC} 1=(3.58,9.80,29.50) \times\left(\frac{1}{157.41}, \frac{1}{68.78}, \frac{1}{29.67}\right)=(0.023,0.142,0.994), \\
& \operatorname{SC} 2=(15.25,27.36,41) \times\left(\frac{1}{157.41}, \frac{1}{68.78}, \frac{1}{29.67}\right)=(0.097,00.398,1.382), \\
& \text { SC3 }=(3.71,9.25,22.25) \times\left(\frac{1}{157.41}, \frac{1}{68.78}, \frac{1}{29.67}\right)=(0.024,0.134,0.750), \\
& \text { SC4 }=(1.71,3.77,20.50) \times\left(\frac{1}{157.41}, \frac{1}{68.78}, \frac{1}{29.67}\right)=(0.011,0.055,0.691), \\
& \text { SC5 }=(3.75,16.24,37) \times\left(\frac{1}{157.41}, \frac{1}{68.78}, \frac{1}{29.67}\right)=(0.024,0.236,1.247), \\
& \text { SC6 }=(1.67,2.36,7.17) \times\left(\frac{1}{157.41}, \frac{1}{68.78}, \frac{1}{29.67}\right)=(0.011,0.034,0.994),
\end{aligned}
$$

The weight vector is determined by applying equations (13) and (14). Subsequently, equation (15) was used to obtain the final weights for each criterion. Table 6 shows the weight vectors and the final normalized weights.

The fuzzy-AHP results show that the cost per room has the highest weight when choosing the places of accommodation which is 0.233 . It is followed by the security level at 0.205 . Free cancellation is the lowest influential criterion with the value 0.066 . Furthermore, the results demonstrate the importance of the rating, where several tourists check out this factor before decision-making. The distance from the center approximately has the same importance as the breakfast availability for choosing places.

4.3. GIS-FAHP Combination. Based on the GIS techniques, the reclassification process is conducted on the criterion maps. This step is essential to figure out the new values based on the new scale from 1 to 10 , except for the free cancellation and breakfast availability where the new scale is 0 or 1 . Figure 6 illustrates the places' spatial distribution in the study area according to the adopted criteria and collected data. The output of the reclassification step handles as the input data of the weighted overlay that deals with raster maps solely. However, the outcomes of the reclassification are vector maps. Therefore, these vector maps were converted into raster by using conversion tools within ArcGIS software. Consequently, FAHP outcomes are combined with the raster maps by using the weighted overlaying tool in GIS to generate the final suitability map as shown in Figure 7.

The final suitability map is generated after conducting the weighted overlay for the case study. The map contains five classes (i.e., "not recommended," "less recommended," "neutral," "recommended," and "highly recommended"). The final map (Figure 7) and the statistical descriptive figure (Figure 8) show realistic results, where the majority of the places are located on Pest side because it is the cultural center of Budapest, and most of the tourist attractions and activities are found in that zone [50]. In addition, the touristic activities and nightlife occurs in the center of Budapest (i.e., district 5, district 6, and district 7). The red pixels in Figure 7 indicate that those places of accommodation are "not recommended" for tourists. 

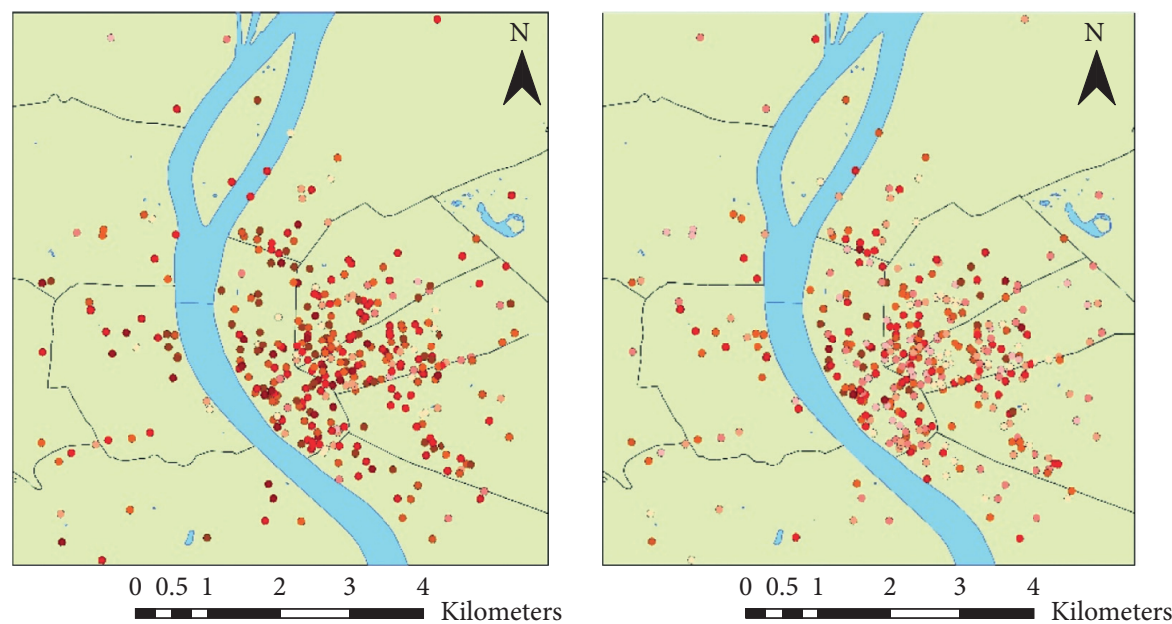

Place rating

- $1.0-1.30$

- $1.3-6.4$

- $6.4-7.2$

- $7.2-7.7$

- $7.7-8.1$

- $8.1-8.5$

- $8.5-8.8$

- $8.8-9.1$

- $9.1-9.4$

- $9.4-9.9$

(a)

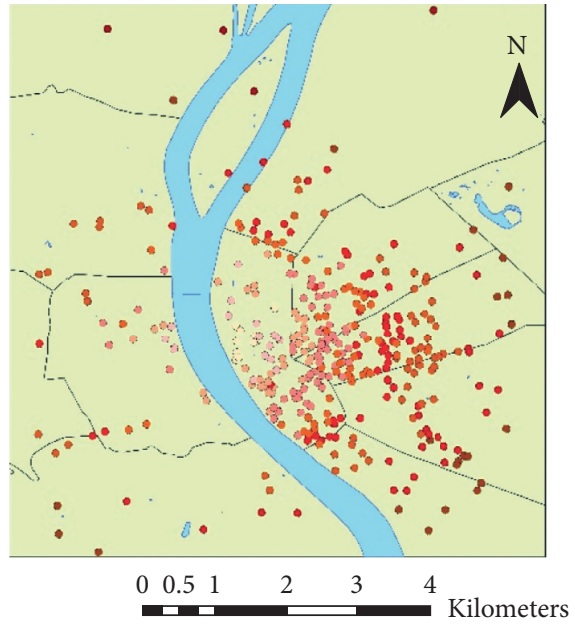

Cost_per_room

- 1790 - 6450

- $6451-10265$

- 10266 - 14000

- $14001-18485$

- $18486-23215$

- $23216-28250$

- $28251-35715$

- 35716 - 48575

- 48576 - 78755

- $78756-150005$

(b)

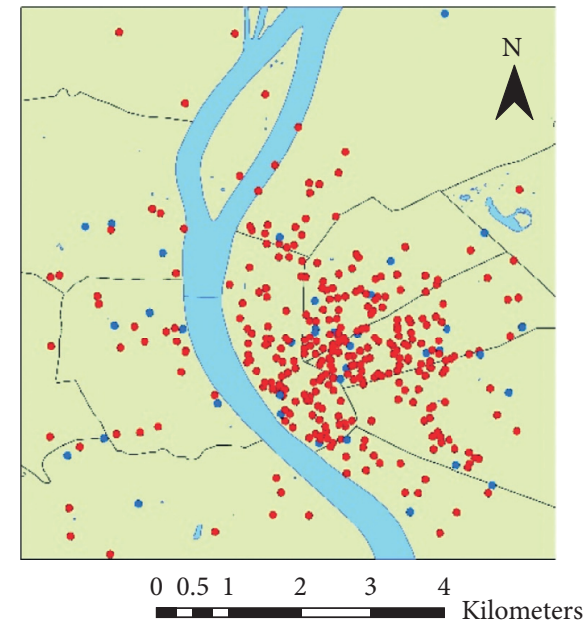

dist_from_center

Breakfast included

- $0.15-0.35$

- 0

- $0.36-0.60$

- 1

- $0.61-0.90$

- $0.91-1.20$

- $1.21-1.50$

- $1.51-1.80$

- $1.81-2.20$

- $2.21-2.70$

- $2.71-3.50$

- $3.51-5.00$

FIgURE 6: Continued. 


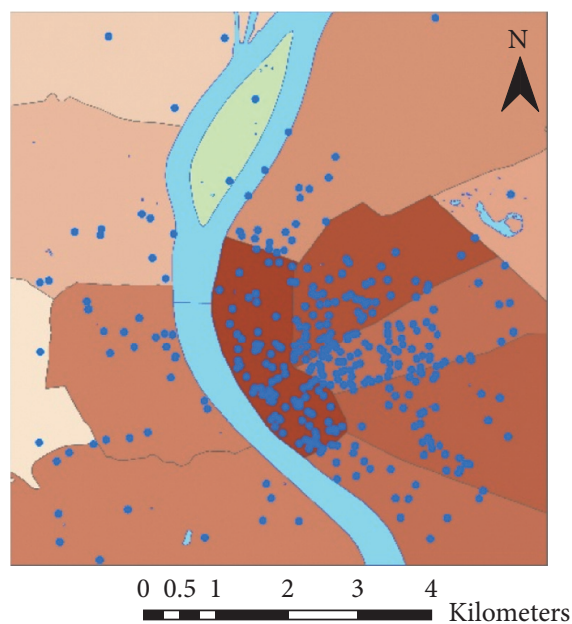

Security_level

Number_of_crimes
\begin{tabular}{|l}
$\square$ \\
$\square$
\end{tabular}
10.46
$10.47-11.12$
$11.13-15.12$
$15.13-15.68$
$15.69-16.67$
$16.68-17.22$
$17.23-33.05$
$33.06-37.29$
$37.30-41.59$
$41.60-65.31$

(e)

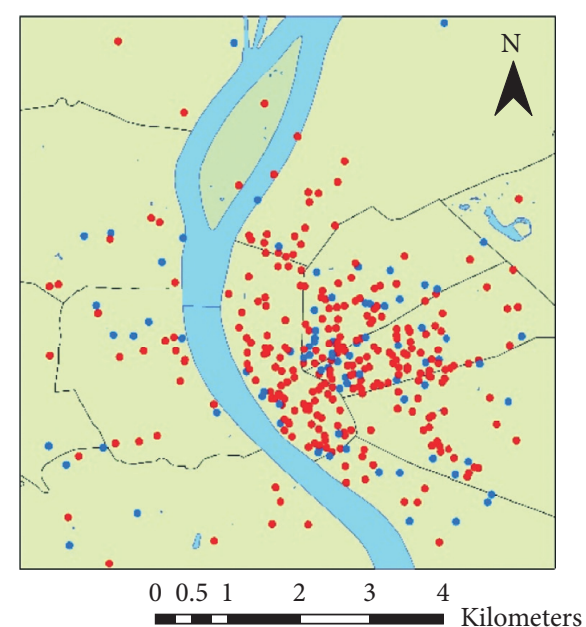

free_cancellation

- 0

- 1

Figure 6: The classification of the alternatives in the study area. (a) Place rating. (b) Cost per room. (c) Distance from center result map. (d) Breakfast availability. (e) Level of security. (f) Free cancellation availability.

However, only two places are with red pixel, which was found in district 5 on Pest side because it has the lowest security level compared to other districts. However, only two places are with red pixel, which was found in district 5 on Pest side because it has the lowest security level, high cost, and the unavailability of the necessary services compared to other places, such as free cancellation and breakfast. Furthermore, it is observed that the "less recommended" places of accommodation with orange pixels are primarily on the side of Pest. Two places with orange color are located on Buda side in district 11, due to the fact that these places are so far from the center of the city, as a result they are "less recommended." The number of accommodation places within the "neutral" category with yellow pixels on the Pest side is more than the Buda side (Figure 8). Several "neutral" places are located mainly in district 6, district 7, and district 8 because of the security level and the low rating, and the cost per room. Most of the accommodations on the side of Buda are either "highly recommended" (indicated by dark green color on the map) or "recommended" (marked by green color on the map). However, the number of "highly recommended" places on the side of Pest is more than double compared to Buda side due to the concentration of the accommodation places on this side. A considerable proportion of "recommended" places are located on Pest side, while less than one in ten can be found in the Buda region.

\section{Discussion}

The findings showed the majority of the accommodation places were recommended or highly recommended for tourist, while the not recommended places were very small portion. The study carried out on the most attractive part of tourist's accommodation. Pinke-Sziva et al. [53] illustrated in their study that tourists preferred the accommodation places located in the city center. This could be easily confirmed from our results, where the spatial distribution of the accommodation places concentrated in the center in Budapest City with more than $65 \%$ of the places falling in the districts 5, 6, and 7 .

Due to the uncertain conditions and the complex decision-making process of tourists, FAHP has been used to weight the criteria. Similar to [15], our results showed that the cost per room was the highest affected criterion for choosing the accommodation place. In contrast to the results of [21], who used the fuzzy method for prioritizing the criteria that influence the tourists' destination, it was found that cost has the least influence. According to [17], it was found that breakfast availability had a significant effect on tourists' choices. There was a difference with our results, where the most affected criteria were the cost, security level, and place rating, followed by the breakfast availability 


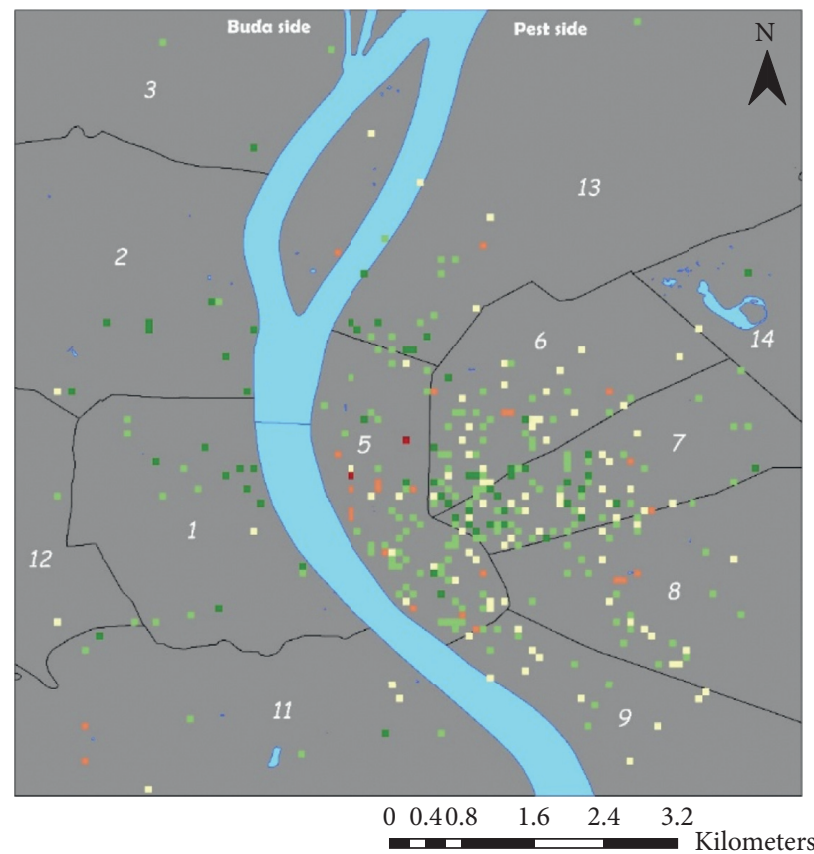

Acc_places-results

Not Recommended

Less Recommended

Neutral

Recommended

Highly Recommended

Figure 7: The final map of accommodations in Budapest City.

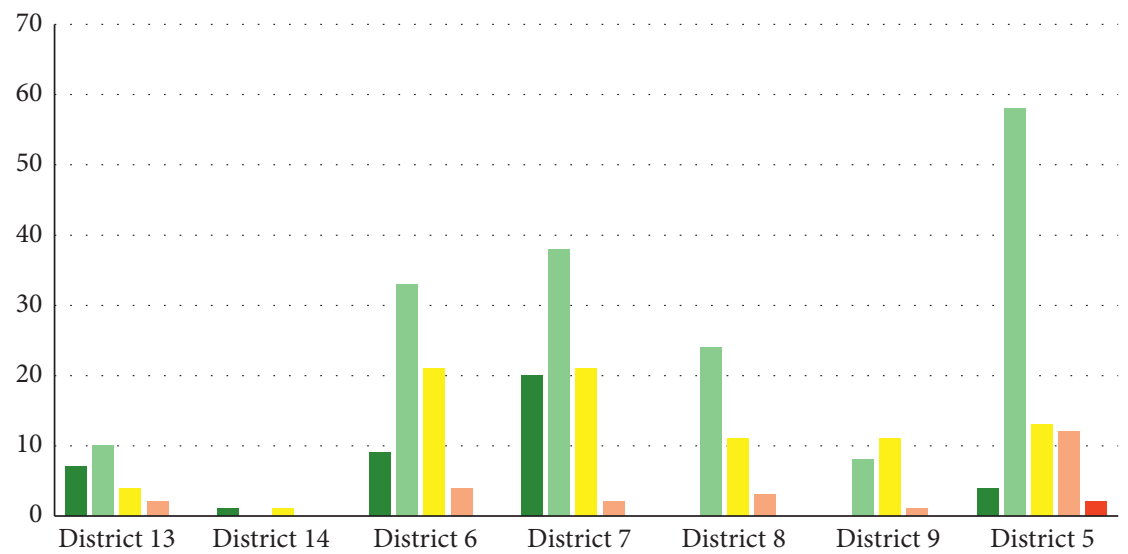

- Highy recommanded

- Recommended

- Neutral

- Less recommanded

not recommanded

(a)

Figure 8: Continued. 


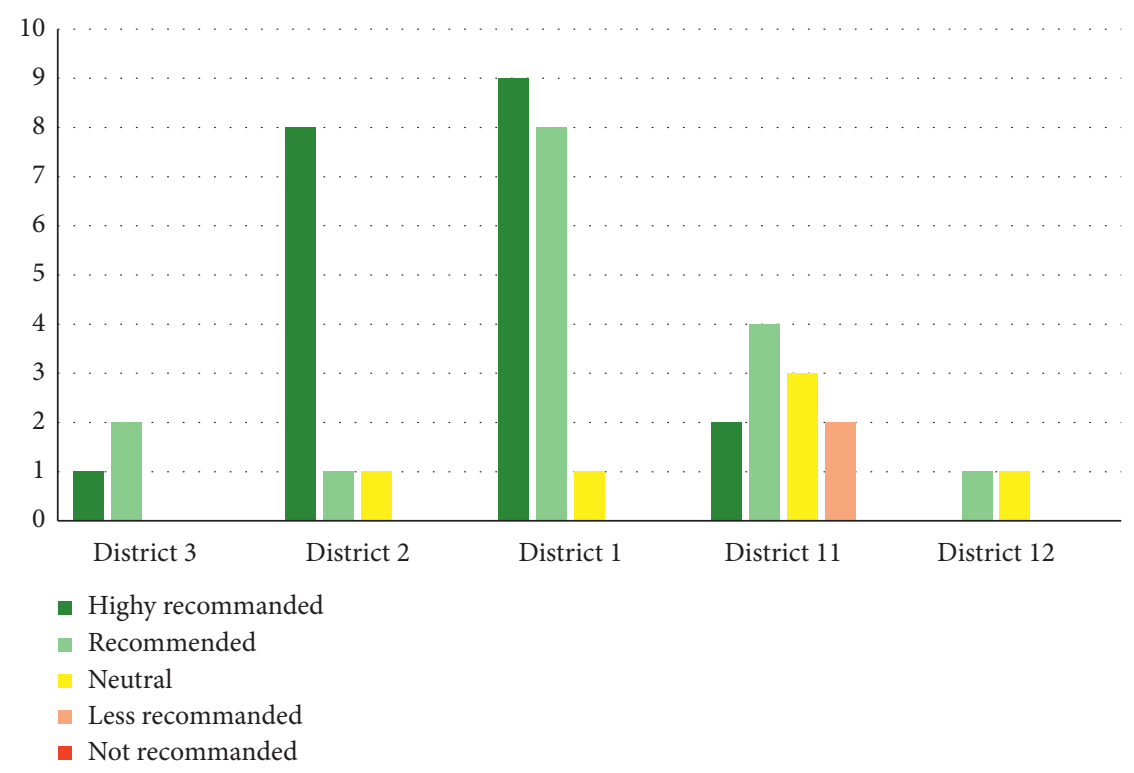

(b)

Figure 8: The places of accommodation per district in both sides of Budapest City. (a) Pest side. (b) Buda side.

criterion. However, this study involved realistic criteria for choosing the optimal accommodation places; thus, it could reflect well the preferences of tourists.

GIS systems were utilized in two main phases. Firstly, the spatial classification of the study area according to the chosen criteria was realized. Based on Figure 6, the accommodation places appeared mainly in the city center represented by districts 5, 6, and 7, and that is clearly obvious that it is because they are close to the touristic attractions, services, and facilities. The spatial classification results demonstrated that the accommodations located in this area had the highest-ranking considering location (i.e., distance from center) criterion. However, the classification findings also showed the lowest level of security in the city center, especially in district 5, which represents the general issues with accommodations in city centers. Generally, it was observed that the level of security in Buda is higher than the Pest side. Meanwhile, there was a diversity of the rating, the cost, and the availability of services observed in the study area. At the second phase, GIS was combined with FAHP to produce the final suitability map of accommodation places. The final map in Figure 7 shows realistic findings. The majority of accommodations on the side of Buda are "recommended" or "highly recommended" with more than $80 \%$, while three-fifths have the same class on the Pest side. The reason for this result might be the difference in the security level, or the accommodations' quality.

This study presented a novel idea of applying the GIS system by overcoming the limitations found in previous studies by the using the overlay tool. Other studies divided the study area into regular square grid cells and linked the weight for each cell. Then, they applied the overlay analysis for the entire study area. Our study considered only the relevant point feature classes (i.e., the accommodation places) and not grid cells. The adopted accommodation place had a unique ID, and each point linked with the FAHP outcomes. Consequently, the number of used cells has been decreased, and a large volume of data was analyzed.

A main limitation of this paper was the survey, which can be extended to involve more criteria affecting the choice of the optimal accommodations. It is recommended to use other methods such as structural equation model (SEM) to reveal unobserved variables. Furthermore, more criteria, such as the accessibility of cultural destinations, might enrich future studies.

\section{Conclusions}

This study aimed to identify the optimal accommodation places in Budapest by combining the fuzzy-AHP method and GIS technique. First, a ranking with the adopted criteria was realized using the FAHP approach. Then, the GIS was applied to develop the final suitability map, which indicates the accommodations according to the five categories from highly recommended to not recommended places. Thus, the proposed model facilitates the decision-making of tourists for selecting the optimal accommodation places in Budapest City.

Realistic criteria represented the tourists' preferences and constraints for choosing an optimal accommodation. Security level, cost per room, distance from the center, place rating, and the availability of breakfast and free cancellation services were the adopted criteria in this study. On both sides of Budapest, altogether 12 districts with 364 places of accommodation were chosen to be examined. Unlike other studies conducted in the same field, this study applied the FAHP-based GIS to eliminate the fuzziness and the uncertainty of selecting the optimal place for accommodation. The importance weight of each criterion was calculated by using FAHP. Then, GIS techniques were used for preparing and digitizing the alternatives (i.e., accommodation places) on the maps and to produce the final suitability map. The 
classification process was performed on the developing maps to formulate the collected data on a unique scale. The considered scale was 1 to 10 on all criteria except for breakfast and free cancellation as these criteria were either 1 or 0 for availability or unavailability, respectively. GIS techniques were used to combine the classified maps with FAHP outcomes to generate the final suitability map.

Based on FAHP results, it was concluded that the cost per room was the highest influential criterion with 0.233 importance weight, followed by the security level with 0.205 . The lowest factor affecting the choice of accommodation was the free cancellation service. Furthermore, it was demonstrated that the place's rating weight importance was 0.182 , while the breakfast and the distance from the center had approximately the same importance. The combination of FAHP and GIS results made the presentation of the places' final suitability map, which contained five classes (i.e., "not recommended," "less recommended," "neutral," "recommended," and "highly recommended") possible. It can be concluded that the majority of the accommodations on Buda side were within the classes of "recommended" or "highly recommended." However, the number of places on Pest side exceeded the four-fifths of the number on the other side. The "recommended" or "highly recommended" places were about $60 \%$ of the total number. A very small number of "not recommended" places not exceeding $1 \%$ were found on Pest side.

Based on the results, the FAHP-GIS combination was found very useful for solving the MCDM-spatial problem. The final suitability map can be adopted for the tourist's decisionmaking process for finding the optimal accommodation. Furthermore, this comprehensive model provides insights on the hotels' competitiveness, which gives a clear direction for the accommodation managers and investors to identify the weaknesses of the existing services and make appropriate enhancements to further strengthen the service quality.

\section{Data Availability}

The data that have been used in our study could be divided into two groups: the attribute data such as the coordination of the accommodation places, rating, and cost. These data were collected from the booking.com website. Octoparse. 8 software is applied to scrape the accommodation places of Budapest. The other type of data was spatial data that were handled using ArcGIS software. These data were collected from Open Street Map (OSM) via QGIS software (version 3.10.9).

\section{Conflicts of Interest}

The authors declare that they have no conflicts of interest.

\section{Acknowledgments}

This paper was supported by the János Bolyai Research Scholarship of the Hungarian Academy of Sciences (BO/ 00090/21/6).

\section{References}

[1] WTTC, Travel and Tourism Economic Impact 2012 World Travel and Tourism Council: Ethiopia, WTTC, London, UK, 2012.

[2] Z. Szabó, Á. Török, and T. Sipos, "Order of the cities: usage as a transportation economic parameter," Periodica Polytechnica Transportation Engineering, vol. 49, no. 2, pp. 164-169, 2021.

[3] HCSO, A magyarlakossa'gkultura'listurizmussalkapcsolat osismeretei, attitu' 'djeie'sutaza'siszoka 'si, HCSO, Tampa, FL, USA, 2015.

[4] W. F. Theobald, "Global tourism," in Global TourismRoutledge, Beijing, China, 2013.

[5] L.-F. Hsieh and L.-H. Lin, "A performance evaluation model for international tourist hotels in Taiwan-An application of the relational network DEA," International Journal of Hospitality Management, vol. 29, no. 1, pp. 14-24, 2010.

[6] N. Shoval, B. McKercher, E. Ng, and A. Birenboim, "Hotel location and tourist activity in cities," Annals of Tourism Research, vol. 38, no. 4, pp. 1594-1612, 2011.

[7] J. Fletcher, A. Fyall, D. Gilbert, and S. Wanhill, Tourism: Principles and Practice, Pearson, London, UK, 2017.

[8] F. E. Otoo, S. Kim, and Y. Choi, "Understanding senior tourists' preferences and characteristics based on their overseas travel motivation clusters," Journal of Travel \& Tourism Marketing, vol. 37, no. 2, pp. 246-257, 2020.

[9] R. K. Dewi, B. T. Hanggara, and A. Pinandito, "A comparison between AHP and hybrid AHP for mobile based culinary recommendation system," International Journal of Interactive Mobile Technologies, vol. 12, no. 1, 2018.

[10] J. Navrátil, R. Švec, K. Pícha, and H. Doležalová, "The location of tourist accommodation facilities: a case study of the Šumava Mts. and South Bohemia tourist regions (Czech Republic)," Moravian Geographical Reports, vol. 20, no. 3, pp. 50-63, 2012.

[11] C. R. Goeldner and J. R. B. Ritchie, Tourism Principles, Practices, Philosophies, John Wiley \& Sons, Hoboken, NJ, USA, 2007.

[12] A. J. Mahdi and D. Esztergár-Kiss, "Variables associated with the tourists' activity chain: definition, grouping, and measurement approaches," in Proceedings of the XIV. IFFK 2020, Budapest, Hungary, October 2020.

[13] N. Losada, E. Alén, J. L. Nicolau, and T. Domínguez, "Senior tourists' accommodation choices," International Journal of Hospitality Management, vol. 66, pp. 24-34, 2017.

[14] F. Bronner and R. De Hoog, "Economizing strategies during an economic crisis," Annals of Tourism Research, vol. 39, no. 2, pp. 1048-1069, 2012.

[15] M. Ananth, F. J. DeMicco, P. J. Moreo, and R. M. Howey, "Marketplace lodging needs of mature travelers," Cornell Hotel and Restaurant Administration Quarterly, vol. 33, no. 4, pp. 12-24, 1992.

[16] T. Lockyer, "Understanding the dynamics of the hotel accommodation purchase decision," International Journal of Contemporary Hospitality Management, vol. 17, no. 6, pp. 481-492, 2005.

[17] B. B. Stringam, J. Gerdes, and D. M. Vanleeuwen, “Assessing the importance and relationships of ratings on user-generated traveler reviews," Journal of Quality Assurance in Hospitality \& Tourism, vol. 11, no. 2, pp. 73-92, 2010.

[18] A. D. Pearman and L. D. Phillips, "Multi-criteria Analysis : a manual multi-criteria analysis: a manual," 2014, https:// assets.publishing.service.gov.uk/government/uploads/ system/uploads/attachment_data/file/7612/1132618.pdf. 
[19] T.-Y. Chou, C.-L. Hsu, and M.-C. Chen, "A fuzzy multicriteria decision model for international tourist hotels location selection," International Journal of Hospitality Management, vol. 27, no. 2, pp. 293-301, 2008.

[20] B. Sohrabi, I. R. Vanani, K. Tahmasebipur, and S. Fazli, “An exploratory analysis of hotel selection factors: a comprehensive survey of Tehran hotels," International Journal of Hospitality Management, vol. 31, no. 1, pp. 96-106, 2012.

[21] T.-K. Hsu, Y.-F. Tsai, and H.-H. Wu, "The preference analysis for tourist choice of destination: a case study of Taiwan," Tourism Management, vol. 30, no. 2, pp. 288-297, 2009.

[22] E. W. T. Ngai and F. K. T. Wat, "Design and development of a fuzzy expert system for hotel selection," Omega, vol. 31, no. 4, pp. 275-286, 2003.

[23] M. H. Vahidnia, A. A. Alesheikh, and A. Alimohammadi, "Hospital site selection using fuzzy AHP and its derivatives," Journal of Environmental Management, vol. 90, no. 10, pp. 3048-3056, 2009.

[24] T. Bahaire and M. Elliott-White, "The application of geographical information systems (GIS) in sustainable tourism planning: a review," Journal of Sustainable Tourism, vol. 7, no. 2, pp. 159-174, 1999.

[25] I. J. Bateman, A. P. Jones, A. A. Lovett, I. R. Lake, and B. H. Day, "Applying geographical information systems (GIS) to environmental and resource economics," Environmental and Resource Economics, vol. 22, no. 1/2, pp. 219-269, 2002.

[26] J. C. García-Palomares, J. Gutiérrez, and C. Mínguez, "Identification of tourist hot spots based on social networks: a comparative analysis of European metropolises using photosharing services and GIS," Applied Geography, vol. 63, pp. 408-417, 2015.

[27] W. Wei, "Research on the application of geographic information system in tourism management," Procedia Environmental Sciences, vol. 12, pp. 1104-1109, 2012.

[28] J. Malczewski, "GIS-based multicriteria decision analysis: a survey of the literature," International Journal of Geographical Information Science, vol. 20, no. 7, pp. 703-726, 2006.

[29] A. T. Ibraheem, A. N. Abid, and A. J. Mehdi, Modern Basics and Methods for Car Parking, Lap Lambert Academic Publishing. VDM Publishing Group, Germany, Riga, Latvia, 2015.

[30] A. K. Mishra, S. Deep, and A. Choudhary, "Identification of suitable sites for organic farming using AHP \& GIS," The Egyptian Journal of Remote Sensing and Space Science, vol. 18, no. 2, pp. 181-193, 2015.

[31] O. Ghorbanzadeh, S. Pourmoradian, T. Blaschke, and B. Feizizadeh, "Mapping potential nature-based tourism areas by applying GIS-decision making systems in East Azerbaijan Province, Iran," Journal of Ecotourism, vol. 18, no. 3, pp. 261-283, 2019.

[32] F. Sahin, M. K. Kara, A. Koc, and G. Sahin, "Multi-criteria decision-making using GIS-AHP for air pollution problem in Igdir Province/Turkey," Environmental Science and Pollution Research, vol. 27, no. 29, pp. 36215-36230, 2020.

[33] J. Alam, "A model for accommodation selection using GIS and multi-criteria system," Global Journal of Human-Social Science: B Geography, Geo-Sciences, Environmental Science \& Disaster Management, vol. 18, no. 3, 2018.

[34] J. M. Sánchez-Lozano, J. Teruel-Solano, P. L. Soto-Elvira, and M. Socorro García-Cascales, "Geographical information systems (GIS) and multi-criteria decision making (MCDM) methods for the evaluation of solar farms locations: case study in south-eastern Spain," Renewable and Sustainable Energy Reviews, vol. 24, pp. 544-556, 2013.
[35] C. Wu, X.-y. Zhang, I.-C. Yeh, F.-y. Chen, J. Bender, and T.-n. Wang, "Evaluating competitiveness using fuzzy analytic hierarchy process-A case study of Chinese airlines," Journal of Advanced Transportation, vol. 47, no. 7, pp. 619-634, 2013.

[36] C. Kahraman, U. Cebeci, and D. Ruan, "Multi-attribute comparison of catering service companies using fuzzy AHP: the case of Turkey," International Journal of Production Economics, vol. 87, no. 2, pp. 171-184, 2004.

[37] Booking, "Booking.com | official site | the best hotels \& accommodation," 2020, https://www.booking.com/index.en-gb. html?label=gen173nr-1BCAEoggI46AdIM1gEaDKI AQGYAQm4AQrIAQXYAQHoAQGIAgGoAgO4 AsuC5PoFwAIB0gIkYjRhZDkxZjAtNDRlMC00 MmY1LTg3YzYtMjc5Yzk5YjQwNmRi2AIF4AIB sid=abe53766c4644976573e7badd0244aa2;keep_landing $=1 \&$ sb_price_type $=$ total $\&$.

[38] PRE-STAT, "Lechner Tudásközpont. (n.d.)," 2021, http://uj. lechnerkozpont.hu/en/oldal/pre-stat.

[39] M. H. Vahidnia, A. Alesheikh, A. Alimohammadi, and A. Bassiri, "Fuzzy analytical hierarchy process in GIS application," The International Archives of the Photogrammetry, Remote Sensing and Spatial Information Sciences, vol. 37, no. B2, pp. 593-596, 2008.

[40] K. M. A.-S. Al-Harbi, "Application of the AHP in project management," International Journal of Project Management, vol. 19, no. 1, pp. 19-27, 2001.

[41] D. L. Peterson, D. G. Silsbee, and D. L. Schmoldt, "A case study of resources management planning with multiple objectives and projects," Environmental Management, vol. 18, no. 5, pp. 729-742, 1994.

[42] R. L. Armacost, P. J. Componation, M. A. Mullens, and W. W. Swart, "An AHP framework for prioritizing customer requirements in QFD: an industrialized housing application," IIE Transactions, vol. 26, no. 4, pp. 72-79, 1994.

[43] A. F. M. Salman, M. J. Skibniewski, and I. Basha, "BOT viability model for large-scale infrastructure projects," Journal of Construction Engineering and Management, vol. 133, no. 1, pp. 50-63, 2007.

[44] T. L. Saaty, "Fundamentals of the analytic hierarchy process," in The Analytic Hierarchy Process in Natural Resource and Environmental Decision Making, pp. 15-35, Springer, New York. NY, USA, 2001.

[45] D.-Y. Chang, "Applications of the extent analysis method on fuzzy AHP," European Journal of Operational Research, vol. 95, no. 3, pp. 649-655, 1996.

[46] G. Büyüközkan and O. Feyzıoglu, "A fuzzy-logic-based decision-making approach for new product development," International Journal of Production Economics, vol. 90, no. 1, pp. 27-45, 2004.

[47] C.-W. Chang, C.-R. Wu, and H.-L. Lin, "Applying fuzzy hierarchy multiple attributes to construct an expert decision making process," Expert Systems with Applications, vol. 36, no. 4, pp. 7363-7368, 2009.

[48] Q. H. Do and J. F. Chen, "Prioritizing the factor weights affecting tourism performance by FAHP," International Journal of Engineering Business Management, vol. 5, no. 1, p. 51, 2013.

[49] C. Kahraman, U. Cebeci, and Z. Ulukan, "Multi-criteria supplier selection using fuzzy AHP," Logistics Information Management, vol. 16, no. 6, pp. 382-394, 2003.

[50] T. Rátz, M. Smith, and G. Michalkó, "New places in old spaces: mapping tourism and regeneration in Budapest," Tourism Geographies, vol. 10, no. 4, pp. 429-451, 2008. 
[51] E. Panyik and T. Rátz, "15. Tourism policy in Hungary: from central planning to multi-level destination management," European Tourism Planning and Organisation Systems, The EU Member States, Brussels, Belgium, pp. 225-242, 2014.

[52] R. Maitland and B. W. Ritchie, City Tourism: National Capital Perspectives, CABI, Wallingford, UK, 2009.

[53] I. Pinke-Sziva, M. Smith, G. Olt, and Z. Berezvai, "Overtourism and the night-time economy: a case study of Budapest," International Journal of Tourism Cities, vol. 5, no. 1, pp. 1-16, 2019. 